\title{
The Evolution of Fruit Tree Productivity: A Review ${ }^{1,2}$
}

\author{
ELIEZER E. GoldSCHMidT
}

Institute of Plant Sciences and Genetics in Agriculture, The Robert H. Smith Faculty of Agriculture, Food and Environment, The Hebrew University of Jerusalem, Rehovot, Israel. goldsmit@agri.huji.ac.il

\begin{abstract}
The Evolution of Fruit Tree Productivity: A Review. Domestication of fruit trees has received far less attention than that of annual crop plants. In particular, very little is known about the evolution of fruit tree productivity. In the wild, most tree species reach reproductive maturity after a long period of juvenility and even then, sexual reproduction appears sporadically, often in a mode of masting. Environmental constraints limit trees' reproductive activity in their natural, wild habitats, resulting in poor, irregular productivity. Early fructification and regular, high rates of productivity have been selected by people, unconsciously and consciously. The reviewed evidence indicates an evolutionary continuum of productivity patterns among trees of wild habitats, intermediary domesticates, and the most advanced domesticates. Alternate bearing appears to represent an intermediate step in the fruit tree evolutionary pathway. The existence of a molecular, genetic mechanism that controls trees' sexual reproduction and fruiting pattern is suggested.
\end{abstract}

\begin{abstract}
果树结果能力的演化: 综述. 与一年生农作物相比,对多年生果树作物的驯化一直来很少受到 关注。尤其是我们对果树结果能力的进化知之甚少。大多数野生果树需要经过相当长的营 养生长阶段才能达到生殖成熟; 即使进入了生殖生长期, 部分果树的有性繁殖也是不连续的, 通常表现为大量结果。环境因素限制了树木在自然或野生环境下的生殖活动, 导致结果能力 差且不规律。人类则有意识和无意识地选择了早产、有规律和高产等性状。本综述提供证 据表明果树结果能力在野生种、中间驯化种和已驯化种之间存在进化连续性,大小年现象似 乎是进化过程中的一个中间步骤。因此,果树间存在一种调控果树有性繁殖和结果模式的遗 传机制。
\end{abstract}

Key Words: Alternate bearing, domestication, masting, sexual reproduction, unconscious selection.

\section{Introduction}

Plant domestication is a very popular topic, subject to multidisciplinary research methodologies (Abbo et al. 2012; Allaby 2010; Burger et al. 2008; Diamond 2002; Doebley et al. 2006; Gepts 2004; Ross-Ibarra et al. 2007; Zeder et al. 2006). However, the vast majority of these studies concern annual crop plants, which constitute the core of human food sources. Only very few studies provide analysis of the domestication of fruit trees and vines.

\footnotetext{
${ }^{1}$ Received 18 December 2011; accepted 20 December 2012; published online 15 January 2013.

${ }^{2}$ Dedication - In loving memory of Professor Elisabeth Goldschmidt, Department of Genetics, The Hebrew University of Jerusalem, Israel.
}

Best known are the pioneer studies of Zohary and Spiegel-Roy (1975) and Zohary and Hopf (2000), which dealt mostly with classical, Old World fruits. Reports about domestication of specific fruit trees are available, but even the most recent ones (Harris et al. 2002; Hughes et al. 2007; Kaniewski et al. 2012; Miller and Schaal 2005; Myles et al. 2011) fail to mention productivity issues and the evolution of these traits has not been addressed.

The purpose of this treatise is to gather and review the relevant fruit tree productivity literature, in an attempt to reconstruct the evolutionary pathway from wild forest trees to the present, domesticated fruit trees.

Whereas "natural selection" (and, in most cases, "ecology") does not apply to changes induced intentionally by humans, the term "evolution" is broader and includes in current 
scientific literature human-induced modifications of nature. Thus, "domestication" is viewed as an integral component of the evolutionary processes (Allaby 2010; Ladizinsky 1998; Zohary 2004). Furthermore, "agriculture" itself is an acknowledged evolutionary arena (Ross-Ibarra et al. 2007; Thrall et al. 2010) and the significance of interactions between the disciplines of evolution and agriculture is well recognized (Moyle and Muir 2010). The term evolution will be used therefore in the present article in its broadest sense, including natural as well as artificial human selection (Gregory 2009).

\section{Characteristics of Fruit Tree Domestication}

Although the domestication of fruit trees took place several millennia after that of cereals and pulses (Janick 2005; Zohary and Hopf 2000), their significance as food sources in ancient times should not be underestimated. Grapes, figs, and dates have been eaten fresh or dried and preserved, using them as concentrated sources of energy, especially during times of famine or wandering. The origins of industrial processing also lie in this domaingrape wine and olive oil have been among the earliest biotechnological food products.

The conceptual difficulties with a definition of "plant domestication" and its overlapping with cultivation and adaptation have been discussed by Harlan (1992a) and Ladizinsky (1998). According to Kislev et al. (2006), domestication in the context of horticulture can be defined as a "major positive change in the edibility of a wild, nonpalatable fruit brought about by a rare genetic event that would disappear without human intervention." Other authorities prefer definitions based on a more concrete, positive human intervention such as propagation or cultivation (Janick 2005). The following definition, adopted from Harlan (1992b: p. 162) seems useful.

Domesticated plants are those brought into the domus which may mean the door yard, garden, field, orchard, wine yard, pasture or ranch... forests and other managed areas. In ecological terms it is the change in habitat that is critical. Genetically, the genes that confer fitness to the new habitat are critical. The genetic architecture of domestication tends in direction of making the plant populations dependent on human interference and manmade habitats.

The importance of Harlan's definition lies in the distinction between the ecological and genetic aspects of domestication, pointing at a central, as yet unresolved theme in the study of domestication.

The domestication of fruit trees has probably followed a different course than that of annual seed plants and may require a somewhat different definition. In particular, there is a difficulty in determining the initial stages of domestication, as demonstrated by the case of kiwi (Actinidia deliciosa [A. Chev.] C. F. Liang and A. R. Ferguson). Kiwifruit vines were growing in the wild in western China since antiquity and the fruit was collected occasionally for human consumption. However, the actual adoption and cultivation of kiwifruit took place only during the twentieth century in New Zealand, outside its biogeographical origin (Huang and Ferguson 2007). Similarly, blueberries (Vaccinium corymbosum L.) and cranberries (Vaccinium macrocarpon Aiton) were gathered from natural stands till the nineteenth century and then gradually developed and transformed into an acknowledged horticultural crop during the twentieth century (Janick 2005).

It is conceivable that crop domestication passed through several intermediary stages before reaching the stage of uniform, single-species cultivated plots (Harris 1989). Wiersum (1997) proposed a special fruit tree domestication model, emphasizing the probable existence of transition steps such as "forest gardens" and "home gardens." Studies of avocado (Persea americana Mill.) and other indigenous Mesoamerican fruit trees point in the same direction (Gama-Campillo and GomezPompa 1992; Hughes et al. 2007). Unlike grain and pulse crops, even a single fruit tree may provide food for a whole family, suggesting a role for small household mixed-crop home gardens, of the kind found in Indonesia, Guatemala (Hawkes 1983), and India (Kumar and Nair 2004). Furthermore, home gardens have presumably enabled serendipitous hybridization among related fruit tree species, thereby playing an important role in their evolution (Hughes et al. 2007).

The traits that are common to most domesticated plants have been designated "The Domestication Syndrome" (Gepts 2004; Hammer 1984). However, not all the traits considered critical in seed plants seem relevant to fruit trees (e.g., the non-shattering of seed and the loss of seed dormancy in cereals). A broader analysis of fruit tree domestication traits is beyond the scope of the present review. The fruit tree productivity-related traits will be discussed in subsequent sections. 


\section{Fruit Tree Productivity Criteria}

Increased yield, as compared with the wild ancestors, is widely accepted as a characteristic of all domesticated crops — seed plants, vegetables, and fruit trees alike. It is, nonetheless, one of the most difficult traits to trace, since the archaeological, ethnographic, paleobotanical, and even recent genetic evidence does not tell us much about the ancient productivity rates. Nevertheless, the increase in fruit size, which is typical to most domesticated fruits (Tanksley 2004; Zhang et al. 2006), can be followed in certain cases (Kislev et al. 2006) and can, perhaps, help in approximating changes in yield. Charred and mineralized seeds of olives, grapes, and dates have been recovered from archaeological sites and used extensively for evolutionary studies (Terral et al. 2012) but correlations between seed dimensions and fruit size cannot be clearly demonstrated. Nevertheless, cob length records enabled estimation of the gradual increase in yield of maize (Zea mays L.) (Evans 1993).

Horticultural evaluation of fruit tree productivity must take various components into account (Autio et al. 1996; Goldschmidt and Monselise 1977; Landsberg 1986). Yield of a given orchard plot, in any one season, can be calculated per tree unit or per area basis. Both tree size and planting density can vary tremendously. For a single tree, yield is a product of fruit weight times the number of fruit units. These are components that are often antagonistic; i.e., excess of fruit units results in smaller fruit. Thus, neither fruit number nor fruit size alone can suffice for the evaluation of fruit tree productivity.

Furthermore, for the long-term economy of a plantation, the age of reproductive maturity, the expected duration, and the consistency of fruitfulness must also be taken into account. Irregular or biennial bearing reduces the average annual yield, thereby affecting crop profitability.

The problem of fruit tree fructification and fruitfulness is complex and would require a broader discussion. However, for the present analysis, the fruit tree productivity target can be defined by the following basic variables:

a) High yield (in tons per hectare or its equivalent);

b) Precocity (minimal juvenile period; i.e., reaching reproductive maturity at an early age);

c) Regular, long-term, non-alternating productivity.

The question that will be addressed in the following sections is how our modern fruit tree cultivars acquired some or all of these characteristics, reaching the current, regular, high rates of productivity.

\section{Historical Records of Productivity}

Ancient scripts often report large-sized fruit (e.g., in the Bible, Numbers 13, 23 "... and cutting down a vine-branch with its grapes, two of them took it on a rod between them..." [Hooke 1965]) and very high yields, but these might be mythical and not represent actual, standard productivity rates. Even seemingly realistic estimates must be treated with caution.

Detailed information can be found in cuneiform scripts about the culture of date palms (Phoenix dactilifera L.), which was already well advanced in ancient Mesopotamia during the third millennia BC (Cocquerillat 1968; Landsberger 1967); maximum yield went as high as $105 \mathrm{~kg}$ per tree (Pruessner 1920), which is in the range of normal productivity even today.

The yield of wine grapes (Vitis vinifera L.) calculated from writings of the Roman horticulturist Columella (Ash 1941) approaches $6,000 \mathrm{~kg} / \mathrm{ha}$, which exceeds the currently recommended wine grape yield. It is clear, though, that Roman horticulture was advanced and sophisticated, as evidenced by the large number of cultivars of every fruit tree and the details of their meticulous cultivation, as described by Columella (Ash 1941), resulting in notable fruitfulness.

The yield of fig trees (Ficus carica L.) was used in Talmudic sources (ca. $200 \mathrm{CE}$ ) to represent the yield of a standard fruit tree orchard. When transformed to current units, a mature fig tree was expected to produce $30 \mathrm{~kg}$ of fresh fruit, which is medium-high in comparison to twentieth century yields of non-irrigated fig plantations in Palestine (Feliks 1979).

\section{Fruiting of Wild Relatives}

Recent decades have witnessed renewed scientific interest in the wild relatives of domesticated crop plants, including fruit trees. On the one hand, the wild relatives can be used to diversify the gene pool and provide material for breeding programs. On the other hand, the study of wild relatives is indispensable for the reconstruction of the domestication process and identification of the progenitors of our modern crop plants. Genetic, marker-assisted analyses have been particularly useful in such investigations (Burger 
et al. 2008; Doebley et al. 2006). However, in the case of fruit trees, the situation is rather complicated. For many of the classical fruit trees, there is a population of wild or semi-wild forms in the vicinity of cultivated areas or in forest habitats (Ladizinsky 1999; Stephan et al. 2003) and it appears to be difficult to distinguish between true, wild forms, escapees, and hybrids between wild and cultured forms. Thus, suggested identification of the progenitors is often controversial. The origin of the cultivated almond (Prunus amygdalus Batsch) is an example (Ladizinsky 1999; Mohamed 2004). Gene flow and introgression from domesticates into their wild relatives further complicates the situation (Ellstrand et al. 1999; Di Vecchi-Staraz et al. 2009). These difficulties prevail even with marker-assisted attempts to define the relationship between the cultivated olive (Olea europeae L.) and the feral olive populations of the Mediterranean, and the reconstruction of the history of olive domestication (Baldoni et al. 2006; Breton et al. 2006; Bronzini de Caraffa et al. 2002; Lavee and Zohary 2012). Apple (Malus domestica Borkh.), on the other hand, is a favorable exception. The wild Malus sierversii (Ledeb.) M. Roem, native to the Tien-Shan mountain range of central Asia, was suggested by Vavilov (1930) to be the ancestor of the domesticated apple, $M$. domestica. The identification of $M$. sieversii as a principal progenitor of the modern apple has been supported by molecular research (Harris et al. 2002; Velasco et al. 2010). While the paleobotanical evolution of the apple and other Rosaceae has now been elucidated (Velasco et al. 2010), the more recent domestication history of the apple clan, including the contribution by the secondary, American diversification center, has also been reconstructed in considerable detail (Janick 2005; Juniper and Mabberley 2006).

Yet, observations on the fruiting of the wild relatives are extremely scarce. In his extensive treatise, Dzhangaliev (2003) included data on the productivity of $M$. sieversii in its wild, forest habitats. Fruit bearing commences at 10 to 12 years and full productivity is attained by 12 to 20 years. Although some trees reach an age of 100 and more years, productivity declines after age 65. Productivity of individual trees depends upon slope, elevation, light, soil, climate, and forest stand density and is extremely variable; in a survey of 130 representative trees yields ranged from 1 to $850 \mathrm{~kg}$ per tree. The year-to-year fluctuations in productivity of individual trees have not been reported. The Polish wild pear (Pyrus pyraster [L.]Burgsd) has an extended juvenility followed by "seed years" and "deaf years" (L. Wolko and W. Antkoviak, pers. comm.). Biennial bearing was also observed with wild apple (Stephan et al. 2003) and wild olive ecotypes (Lavee 2006).

An opportunity to study the fruiting of the wild apple $M$. sieversii has been brought about by trees raised from seed collected from the wild in Kazakhstan by Forsline and his team (Forsline et al. 2003) and planted as experimental plots in Geneva, New York. A follow-up of the bloom intensity of these trees during their first 12 years (P. L. Forsline and G. M. Volk, pers. comm.) shows that while three to four years old, there was almost no bloom, at five to six years old, almost all the trees flowered, some rather profusely, and by the age of eight to nine years old, most trees bloomed heavily. Thus, M. sieversii does not have an extended period of juvenility. Furthermore, inspection of the yearly bloom intensity records of more than 1,000 trees for 12 years did not reveal a pattern of biennial bearing. There were, of course, some yearly fluctuations but these very rarely reached extreme alternate bearing patterns. These preliminary records must be considered with care, however, since cultural conditions and some pruning may have altered the natural fruiting pattern of wild $M$. sieversii trees.

\section{Recently Domesticated Fruit Trees}

Deeper insight into the fruiting patterns of fruit trees can be gleaned from recently domesticated fruit trees, which are only very few generations away from their wild ancestors.

The pecan nut (Carya illinoiensis [Wangenh.] $\mathrm{K}$. Koch) belongs to this category; its adoption as a cultivated fruit tree took place in North America less than two centuries ago. Pecan appears to have been a forest tree with a typical masting behavior, as observed even today with wild pecans (M. W. Smith, pers. comm.). The "domesticated" pecans still reveal a strong alternate bearing habit, which can be "calmed down" considerably, but not entirely overcome, by careful horticultural management. Climate and defoliation pests continue to have a dominating influence on pecan fruiting behavior, even under modern plantation conditions (Sparks 1986).

Macadamia (Macadamia F. Muell) is another recently domesticated tree. It originated in 
Australia, but its development as a commercial crop began in Hawai' $\mathrm{i}$ during the twentieth century (Hardner et al. 2009). In the Australian rainforest, macadamia trees flower and produce fruit scarcely and irregularly; 2.5 fruit were produced on average per fruiting tree (Neal et al. 2010). Cultivation and extensive selection efforts have gradually led to yield improvement, without conspicuous alternate bearing (Hardner et al. 2009). Seedling macadamia trees under cultivation reach reproductive maturity between four and six years after planting, with one to two years in the nursery prior to that. But in the wild, some trees do not flower for at least 20 years, depending on the environment.

Thus, the experience acquired with some of the recently domesticated fruit trees demonstrates the link between the wild, forest tree progenitors and their domesticated descendants that retain, nonetheless, some of the reproductive patterns of their ancestors.

\section{Current Fruit Tree Domestication Attempts}

Demonstration of the existence of presumed intermediary forms is a major difficulty in evolutionary research. Examination of current fruit tree domestication efforts might, therefore, shed light on early stages of the fruit tree domestication processes (Akinnifesi et al. 2004; $\mathrm{Li}$ et al. 2010). Initiatives to adopt new, indigenous fruit trees for the benefit of small household farmers in developing countries, mainly in Africa, but also in Asia, Latin America, and Oceania, are extremely interesting in this context.

A comprehensive description of such efforts and the research approaches involved can be found in Simons and Leakey (2004) and in Akinnifesi et al. (2004). In addition to the wellknown heterozygosity of fruit trees, resulting in a high degree of genetic variability, a major obstacle on the way to improvement is the strong genotype $\mathrm{X}$ environment interaction. The preferable initial step is the screening of numerous seedling provenances of the desired species in several areas in order to find the ones that are most successful and least site-dependent. The select provenances can then be the starting point for vegetative propagation, leading to the establishment of clones (Akinnifesi et al. 2004). The move towards vegetative propagation resulted in dramatic reduction of juvenility (Akinnifesi et al. 2004). The African plum, (Dacryodes edulis H.J.
Lam) is an important indigenous fruit tree of West and Central Africa. A study of 100 trees growing in a rural community in Nigeria examined fruit and tree characteristics. Large variability was found in fruit quality traits as well as in tree characteristics. Farmers reported first fruiting from age 3 up to 22 years (Anegbeh et al. 2005). Akinnifesi et al. (2004) describe on-going work with more than 20 priority indigenous fruit trees. The earliest step of the domestication program is persuasion of farmers to cultivate the indigenous tree as an alternative to wild fruit collection. In addition to much variability in fruit and tree parameters, yields are subject to tremendous year-to-year variation, being strongly influenced by the environment. Delayed or suppressed reproduction under environmental stress is a conservative strategy of survival that must be changed through selection.

The overall emerging picture reflects a primeval domestication scenario, which has presumably occurred with the classical fruit tree crops several millennia ago.

\section{Conscious and Unconscious Selection in Fruit Tree Domestication}

Viewing plant domestication as an evolutionary process has prompted Zohary (2004) to sharpen the distinction between two types of selection: a) conscious or intentional selection applied by growers and breeders for traits of interest to them; and b) unconscious or automatic selection brought about because the plants concerned were removed from their original wild habitats and placed in different, human-managed environments, thereby exposing them to different selective pressures. These definitions apply, of course, also to the domestication of fruit trees. According to Zohary (2004) several critical steps in fruit tree domestication were undertaken unconsciously or unintentionally, at least initially.

The first, most ancient step was the shift from sexual seed propagation to vegetative propagation by cuttings, layering, or offshoots (Zohary and Hopf 2000; Zohary and Spiegel-Roy 1975). This shift was vital for the preservation and perpetuation of select phenotypes discovered in the wild, which would have been lost by seed propagation due to out-crossing with the wild, heterozygous tree population. Although valid for most fruit trees, there are some old domesticate exceptions such as mango (Mangifera indica L.) that, in India, was mostly propagated by seed (Mukherjee 1953). 
There is an evolutionary price, however, to the long-term use of vegetatively-propagated clones; namely, narrowing of the genetic basis and loss of biodiversity that endangers and, in extreme cases, precludes further breeding improvement (Harris et al. 2002; Janick 2005). According to Myles et al. (2011), the widespread adoption of vegetative propagation was a double-edged sword. Although beneficial by preserving and ensuring true breeding cultivars, it also precluded further cultivar improvement and disease resistance by crosses.

The adoption of vegetative propagation affected tree productivity primarily by the reduction of juvenility. Trees originating from cuttings reach reproductive maturity sooner than seedlings, and other symptoms of juvenility, such as the thorniness of Citrus, are also suppressed. The next step, the origin of which is also shrouded in mystery, was the invention of grafting (Mudge et al. 2009). The introduction of grafting was indispensable for propagation of species such as apple that are difficult to root (Janick 2005; Zohary and Hopf 2000). Grafting represents a further step in the enhancement of fruit tree productivity, since the scion is adult from the start, and thus the grafted tree does not have to go through the whole transition from juvenility to adulthood. Although used originally, likely as a means to enable the propagation of select phenotypes, grafting became a major intentional selection tool for soil and climate adaptation, disease resistance, improved productivity, and fruit quality. Thus, the grafted tree, which benefits from the desired properties of two distinct genotypes, became the "central pillar" of the entire modern fruit tree culture.

Of particular relevance is the effect of dwarfing rootstocks, used for centuries in apple and pear, and studied in greatest detail in apple. A more compact growth habit is one of the acknowledged plant domestication traits (Gepts 2004). Graft-dwarfed apple trees attain a higher Harvest Index, indicating a more efficient fruit-oriented partitioning of dry matter (Atkinson and Else 2004; Palmer 1988; Webster 2002) and an advanced step in the evolution of fruit tree productivity.

Studies of fruit trees reveal a complex array of genetic, species-specific changes in reproductive biology, which most probably arose by spontaneous mutations. According to Zohary and SpiegelRoy (1975), the revolutionary move towards vegetative propagation brought about a break- down of natural pollination systems. This imposed a serious limitation on fruit production, particularly in dioecious species like date, fig, and grape. The wild-type pattern of pollination was replaced by artificial pollination that requires a limited number of male trees, supplemented by human transfer of pollen. However, further, natural solutions to these difficulties were provided by the genetic shift from dioecism to hermaphroditism in Vitis (Ladizinsky 1998) and by the parthenocarpy of the common fig and certain varieties of grape and citrus. Although the genetics of hermaphroditism in the grape vine has been worked out (Ladizinsky 1998), close to nothing is known about the acquisition of this trait, whether from the wild or during the course of domestication.

The carob (Ceratonia siliqua L.), a relatively recent domesticate (Zohary 2002), is an interesting test case. In most wild populations the carob is dioecious but, along the coast of the Iberian Peninsula, there is a considerable percentage of trees with perfect, hermaphrodite flowers. Most domestic carob clones are female, yet some of the traditional cultivars have perfect flowers. According to Zohary (2002), this complex situation indicates that the carob underwent only a partial breakdown of dioecy, reflecting its intermediate, incomplete domestication.

Additional reproductive traits include changes in ploidy and pollen incompatibility barriers. Most flowering plants, including fruit trees, have gone through one or more polyploidic events (Liu and Adams 2010; Meyers and Levin 2006). The effects of polyploidy are diverse and may include changes in gene function (Liu and Adams 2010) and loss of self-incompatibility (Robertson et al. 2010). Mutations causing breakdown of selfincompatibility have been found in several species of Prunus (Zohary 2004).

Modern fruit tree biology comprises a wealth of diverse variants within the sexual reproductive processes (Janick 2005; Sedgley and Griffin 1989). This indicates that extensive genetic changes must have taken place in the reproductive biology of domesticated trees, in spite of the relatively short evolutionary time span. As pointed out by Janick (2005), we are greatly indebted to the anonymous individuals who were the first to identify such phenotypes and propagate them, perhaps without fully comprehending the profound, long-term implications of their selection 


\section{Strategies of Sexual Reproduction in Trees}

Unlike annual seed plants, the short-term survival of the individual tree does not depend upon regular sexual reproduction. The perennial nature of trees allows them to spend several years, in some forest trees up to several decades, building their vegetative skeleton before attaining reproductive maturity (Wareing 1959). But even then, wild tree species do not seem to flower and set fruit regularly. Many woody plants seem to adhere to alternating, supra-annual schedules consisting of either high or low reproduction years. This extreme cyclic fruiting pattern is known as "mast seeding" (Herrera et al. 1988). Masting behavior is under intensive investigation, attempting to discover the ultimate and proximate eco-physiological reasons of this phenomenon, using mathematical models (Kelly and Sork 2002; Tachiki and Iwasa 2010). Large year-toyear variability in the intensity of the flowering of wild trees and shrubs is evident even where striking masting behavior has not been identified.

However, sexual reproduction is eventually necessary-even in trees-since seed production is the principal natural mechanism for the perpetuation and survival of the natural species in the wild. Yet, seeds play no role in parthenocarpic cultivars and many other "human-made" domesticates that are entirely dependent on vegetative propagation.

Sexual reproduction is a costly and highly exhaustive plant process (Bustan et al. 1995; Sedgley and Griffin 1989). Massive sexual reproduction, i.e., conversion of all the vegetative buds to reproductive ones, uses up all of a tree's reserves. The tree may collapse (Smith 1976), or at least need to take a year or several years' pause in order to replenish its nutrient resources. This may drive the tree into an alternate bearing, on/ off cycle (Goldschmidt 2005; Monselise and Goldschmidt 1982). The prevention of excessive fruit production is achieved in nature by the selfthinning mechanism that adjusts the final number of fruit per tree to the tree's fruit-bearing abilities (Goldschmidt and Monselise 1977). Mango, avocado, and olive trees, just to mention a few examples, produce a tremendous number of flowers but only a small percentage of these flowers set fruit and further, fine adjustment is attained by subsequent waves of fruitlet abscission. Where the natural, self-thinning mecha- nism is not efficient enough, manual or chemical fruit thinning treatments are commonly applied.

There is yet another, often overlooked, basic constraint that precludes conversion of all of trees' vegetative meristems into reproductive ones. This is the necessity, shared by all polycarpic plants (Albani and Coupland 2010; Lang 1965), to retain a reserve of vegetative buds in order to secure the trees' future growth. The extent of this vegetative reserve may vary considerably, allowing for a broad range of proportional division between vegetative growth and reproductive activity. Thus, the maintenance of a balance between vegetative and reproductive activities turns out to be a major realm of internal, physiological tree management and survival. This is apparently a subtle, highly sensitive matter and the precise mechanisms are as yet poorly understood. Carbohydrates, mineral nutrients, and plant hormone resources are certainly involved, but an overriding, genetic regulatory mechanism must be assumed, to the best of our comprehension.

Furthermore, unlike fruit characteristics, the principal genetics of which appears to be straightforward (Tanksley 2004), the genetics of yield is complex and insufficiently understood, as shown even in an extensively investigated annual crop like tomato (Grandillo et al. 1999; Gur and Zamir 2004). Recent attempts to genetically analyze grape fruitfulness demonstrate this complexity (Doligez et al. 2010). Thus, the genetic basis of fruit tree productivity still waits to be deciphered.

It has been in people's agricultural-commercial interest to achieve a regular fruiting norm for their fruit crops. There seem to be relatively few fruit tree crops that are well balanced naturally and bear fruit regularly and consistently. The fig is one representative of this desirable pattern. Interestingly, the regular bearing of the fig is already mentioned in ancient Talmudic sources (Neusner 1991). Most fruit trees reveal nonetheless some degree of fluctuation and alternation, in particular under suboptimal conditions and biotic or abiotic stress (Monselise and Goldschmidt 1982). Alternate bearing is widespread among fruit trees of diverse botanical genera and climates even today; deciduous (apple, pecan, pistachio [Pistacia vera L.]) as well as evergreens (carob, Citrus, olive, mango) are prone to alternation. Pistachio (Stevenson and Shackel 1998) and olive (Bustan et al. 2011) are particularly interesting 
since their alternate fruiting pattern does not correlate with carbohydrate cycling.

The ubiquity of the alternation phenomenon indicates that it reflects one of the most innate traits of trees' reproductive system (Goldschmidt 2005). Alternation of reproductive years with fruitless, vegetative years appears to be one of the strategies devised by nature for balancing trees' sexual reproduction with the required perpetuation of vegetative growth and retrieval of nutritional resource, both of which are necessary for the organism's survival. Alternate bearing represents, according to this view, an intermediate stage in the domestication pathway, between the masting and irregular sexual reproduction patterns of wild, forest trees and the consistent, relatively stable fruiting of modern fruit tree plantations.

\section{Concluding Remarks}

Fruit tree domestication has received limited attention compared with that of annual crop plants. The acquisition of fruit tree productivity, in particular, has scarcely been investigated. Viewing fruit trees as descendants of wild forest trees places the changes in fruit tree productivity patterns in an evolutionary perspective. Adoption of the mathematical-modeling approach employed in masting research appears to be instructive. Examining productivity patterns of classic, recently domesticated and newly adopted fruit trees provides clues to the stepwise transformation of the wild forest tree into the modern plantation tree. This presumed evolutionary continuum is illustrated in Table 1.

To a large extent, the flowering and fruiting of trees in their wild, natural habitats is dominated by the environment - the surrounding wild vegetation, availability of sunlight, water, and min- eral nutrients, and biotic and abiotic stresses, all of which interfere and restrict fruit production. Consequently, under wild conditions, sexual reproduction of tree species is highly fluctuant, often revealed in a masting habit, and full expression of the fruiting potential is seldom attained. Fruit tree domestication involved adoption of vegetative propagation and grafting, enabling maintenance of select clones and minimizing juvenility. In spite of the short evolutionary distance between modern fruit trees and their wild progenitors, fundamental changes in the reproductive biology of trees can be discerned. Presumably, human-selected mutations bypassed the obstacles of dioecy and incompatibility, leading in some cases to parthenocarpic fruiting.

Domestication has gradually alleviated environmental and biological stresses, thereby reducing yearly fluctuations and increasing yield. Agricultural practices such as pruning, girdling, and fruit thinning serve as tools for maintaining a golden path between excessive reproductive activity and ground level vegetative growth. The changes from seed breeding to vegetative propagation and sophisticated, seed-independent reproductive mechanisms are also indicated in Table 1. Fruit tree species can be arranged along an evolutionary scale, according to the genetic and physiological distance from their wild progenitors. Grapevines and apples will probably be the specifics in the Domesticated column of the table. On the least domesticated end, the Wild column, recent domesticates like pecan, macadamia, and kiwi would find their place. Olive, pistachio, and carob may occupy their place in the Intermediate column.

The evidence concerning the step-wise acquisition of fruit tree productivity has led us to

Table 1. Presumed EVOlUtionary STEPS OF FrUIT TREE DOMESTICATION AND PRODUCTIVITY.

\begin{tabular}{|c|c|c|}
\hline$\overline{\text { Wild }}$ & Intermediate & Domesticated \\
\hline Native, forest habitat & $\begin{array}{l}\text { Vicinity of human settlements, } \\
\text { Home gardens }\end{array}$ & Highly managed habitats \\
\hline Seed reproduction & Seed and/or vegetative propagation & Vegetative propagation, grafting \\
\hline Dioecious & Mixed-type flowering & $\begin{array}{l}\text { Hermaphrodites, parthenocarpic } \\
\text { fruiting }\end{array}$ \\
\hline Extended juvenility & Reduced juvenility & Juvenility short, or absent \\
\hline $\begin{array}{l}\text { Environmental constraints, wild } \\
\text { plant competition, biotic and } \\
\text { abiotic stresses }\end{array}$ & Partial relief of environmental stresses & $\begin{array}{l}\text { Management of nutritional and } \\
\text { biotic stresses }\end{array}$ \\
\hline Irregular fruiting, masting & Alternate bearing & Regular fruiting \\
\hline
\end{tabular}


postulate a basic, presumably genetic program that controls the frequency and intensity of sexual reproduction in trees. Fruit trees should be viewed as a specific segment within the broader tree category.

The currently emerging, sequenced genomes of fruit tree species (Myles et al. 2011; Velasco et al. 2010) will open the way for further detailed analysis of the genetic changes that have occurred during the history of fruit tree domestication and cultivation, including the evolution of tree productivity.

\section{Acknowledgements}

The present study would not be possible without the help of expert colleagues who kindly provided details of various fruit tree crops and some unpublished data (B. Bravdo, C. M. Hardner, M. Smith, G. Volk, L. Wolko, and D. Zamir) as well as invaluable comments on early versions of the manuscript (S. Abbo, A. Ashri, J. Janick, G. Ladizinsky, A. N. Lakso, and S. Lavee). Special thanks are due to Editor-in-Chief, R. Voeks and Associate Editor, A. Vilela, for their help and support in the processing of the manuscript. J. Shi and J-B. Luan kindly prepared the Chinese Abstract. M. Huberman kindly helped with arrangement and submission of the manuscript. Their help is gratefully acknowledged.

Open Access This article is distributed under the terms of the Creative Commons Attribution License which permits any use, distribution, and reproduction in any medium, provided the original author(s) and the source are credited.

\section{Literature Cited}

Abbo, S., S. Lev-Yadun, and A. Gopher. 2012. Plant domestication and crop evolution in the Near East: On events and processes. Critical Reviews in Plant Sciences 31: 241-257.

Albani, M. C. and G. Coupland. 2010. Comparative analysis of flowering in annual and perennial plants. Current Topics in Developmental Biology 91:323-348.

Allaby, R. 2010. Integrating the processes in the evolutionary system of domestication. Journal of Experimental Botany 61:935-944.

Akinnifesi, F. K., F. R. Kwesiga, J. Mhango, T. Chilanga, and R. Swai. 2004. Domestication priority for Miombo indigenous fruit trees as a promising livelihood option for small-holder farmers in Southern Africa. Acta Horticulturae 632:15-30.

Anegbeh, P. O., V. Ukafor, C. Usoro, Z. Tchoundjeu, R. R. B. Leakey, and K. Schreckenberg. 2005. Domestication of Dacryodes edulis: 1. Phenotypic variation of fruit traits from 100 trees in southeast Nigeria. New Forest 29:149-160.

Ash, H. B. 1941. On Agriculture, I: Books 1-4 by Columella. Cambridge, Massachusetts: Harvard University Press.

Atkinson, C. J. and M. A. Else. 2004. Enhancing Harvest Index in temperate fruit tree crops through the use of dwarfing rootstocks. In: Proceedings of the International Workshop on Cocoa Breeding for Improved Production Systems, October 19-21, 2003, eds., F. Bekele, M. J. End, and A. B. Eskes, 118-131. Accra, Ghana: INGENIC and the Ghana Cocoa Board. Autio, W. R., D. W. Greene, and W. J. Lord. 1996. Performance of 'McIntosh' apple trees on seven rootstocks and a comparison of methods of productivity assessment. HortScience 31:11601163.

Baldoni, L., N. Tosti, C. Riccolini, A. Belaj, S. Arcioni, G. Pannelli, M. A. Germana, M. Mulas, and A. Porceddu. 2006. Genetic structure of wild and cultivated olives in the central Mediterranean basin. Annals of Botany 98:935-942.

Breton, C., G. Besnard, and A. A. Berville. 2006. Using multiple types of molecular markers to understand olive phylogeography. In: Documenting Domestication: New Genetic and Archaeological Paradigms, eds., M. A. Zeder, D. G. Bradley, E. Emshwiller, and B. D. Smith, 143-152. Berkeley, California: University of California Press.

Bronzini de Caraffa, V., J. Maury, C. Gambotti, C. Breton, A. Berville, and J. Giannettini. 2002. Mitochondrial DNA variation and RAPD mark oleasters, olive, and feral olive from Western and Eastern Mediterranean. Theoretical and Applied Genetics 104:1209-1216.

Burger, J. C., M. A. Chapman, and J. M. Burke. 2008. Molecular insights into the evolution of crop plants. American Journal of Botany 95:113-122.

Bustan, A., A. Avni, S. Lavee, I. Zipori, Y. Yeselson, A. A. Schaffer, J. Riov, and A. Dag. 2011. Role of carbohydrate reserves in yield production of intensively cultivated oil olive (Olea europaea). Tree Physiology 31:519-530. 
Y. Erner, and E. E. Goldschmidt. 1995. Interactions between developing Citrus fruits and their supportive vascular system. Annals of Botany 76:657-766.

Cocquerillat, D. 1968. Palmearies et cultures de l'Enna d'Uruk (559-520). Ausgrabungen der Deutschen Forscungsgemeinschaft in UrukWarka 8, Gebr. Berlin: Mann Verlag.

Diamond, J. 2002. Evolution, consequences and future of plant and animal domestication. Nature 418:700-707.

Di Vecchi-Staraz, M., V. Lacou, G. Bruno, T. Lacombe, S. Gerber, T. Bourse, M. Boselli, and P. This. 2009. Low level of pollen-mediated gene flow from cultivated to wild grapevine: Consequences for the evolution of the endangered subspecies Vitis vinifera L. subsp. silvestris. Journal of Heredity 100:66-75.

Doligez, A., Y. Bertrand, S. Dias, J.-F. Ballester, A. Bouquet, and P. This. 2010. QTLs for fertility in table grape (Vitis vinifera L.). Tree Genetics and Genomics 6:413-422.

Doebley, J. F., B. S. Gaut, and B. D. Smith. 2006. The molecular genetics of crop domestication. Cell 127:1309-1321.

Dzhangaliev, A. D. 2003. The wild apple tree of Kazakhstan. Horticultural Reviews 29:63-303.

Ellstrand, N. C., H. C. Prentice, and J. F. Hancock. 1999. Gene flow and introgression from domesticated plants into their wild relatives. Annual Review of Ecology and Systematics 30:539-563.

Evans, L. T. 1993. Crop evolution, adaptation and yield. Cambridge, United Kingdom: Cambridge University Press.

Feliks, Y. 1979. Talmud Yerushalmi Tractate Sheviit. Jerusalem, Israel: Zur-Ot Press.

Forsline, P. L., H. S. Aldwinckle, E. E. Dickson, J. J. Luby, and S. C. Hokanson. 2003. Collection, characterization, and utilization of wild apples of Central Asia. Horticultural Reviews 29:1-62.

Gama-Campillo, L. and A. Gomez-Pompa. 1992. An ethnoecological approach for the study of Persea: A case study in the Maya area. In: Proceedings of the 2nd World Avocado Congress, ed., C. J. Lovatt, 11-17. Riverside, California: University of California Riverside and California Avocado Society.

Gepts, P. 2004. Crop domestication as a longterm selection experiment. Plant Breeding Reviews 24(2):1-44.

Goldschmidt, E. E. 2005. Regolazione dell'alternanza di produzione negli alberi da fruto (Italia). Italus Hortus 12:11-17.
— and S. P. Monselise. 1977. Physiological assumptions toward the development of a Citrus fruiting model. In: Proceedings of the International Society of Citriculture, ed., W. Grierson, 2:668-672. Lake Alfred, Florida: International Society of Citriculture.

Grandillo, S., D. Zamir, and S. D. Tanksley. 1999. Genetic improvement of processing tomatoes: A 20 years perspective. Euphytica 110:85-97.

Gur, A. and D. Zamir. 2004. Unused natural variation can lift yield barriers in plant breeding. PLoS Biology 2:1610-1615.

Gregory, T. R. 2009. Artificial selection and domestication: Modern lessons from Darwin's enduring analogy. Evolutionary Education Outreach 2:5-27.

Hammer, K. 1984. Das Domestikationssyndrome. Kulturpflanze 32:11-34.

Hardner, C. M., C. Peace, A. J. Lowe, J. Neal, P. Pisanu, M. Powell, A. Schmidt, C. Spain, and K. Williams. 2009. Genetic resources and domestication of macadamia. Horticultural Reviews 35:1-125.

Harlan, J. R. 1992a. Crops and man, 2nd ed. Madison, Wisconsin: American Society of Agronomy.

- 1992b. Origin and processes of domestication. In: Grass Evolution and Domestication, ed., G. P. Chapman, 159-175. Cambridge, UK: Cambridge University Press.

Harris, D. R. 1989. An evolutionary continuum of people-plant interaction. In: Foraging and farming, the evolution of plant exploitation, eds., D. R. Harris and G. C. Hillman, 11-26. London: Unwin Hyman.

_ J. P. Robinson, and B. E. Juniper. 2002. Genetic clues to the origin of the apple. Trends in Genetics 18:426-430.

Hawkes, J. G. 1983. The diversity of crop plants. Cambridge, Massachusetts: Harvard University Press.

Herrera, C. M., P. Jordano, J. Guitian, and A. Traveset. 1988. Annual variability in seed production by woody plants and the masting concept: Reassessment of principles and relationship to pollination and seed dispersal. American Naturalist 154:576- 594.

Hooke, S. H., ed. 1965. Bible in Basic English. Cambridge, United Kingdom: Cambridge University Press, in Association with Evans Brothers, Ltd. 
Huang, H. W. and A. R. Ferguson. 2007. Genetic resources of kiwifruit domestication and breeding. Horticultural Reviews 33:1-121.

Hughes, C. E., R. Govindarajulu, A. Robertson, D. L. Filler, S. A. Harris, and C. D. Bailey. 2007. Serendipitous backyard hybridization and the origin of crops. Proceedings of the National Academy of Sciences of the United States of America (PNAS) 104(36):14389-14394.

Janick, J. 2005. The origin of fruits, fruit growing and fruit breeding. Plant Breeding Reviews 25:255-320.

Juniper, B. E. and D. J. Mabberley. 2006. The story of the apple. Portland, Oregon: Timber Press.

Kaniewski, D., E. Van Campo, T. Boiy, J.-F. Terral, B. Khadari, and G. Besnard. 2012. Primary domestication and early uses of the emblematic olive tree: Palaeobotanical, historical and molecular evidence from the Middle East. Biological Reviews 87(4):885-899.

Kelly, D. and V. L. Sork. 2002. Mast seeding in perennial plants: Why, how, where. Annual Review of Ecology and Systematics 33:427-447.

Kislev, M. E., A. Hartmann, and O. Bar-Yosef. 2006. Early domesticated fig in the Jordan valley. Science 312:1372-1374.

Kumar, B. M. and P. K. R. Nair 2004. The enigma of tropical homegardens. Agroforestry Systems 61:135-152.

Ladizinsky, G. 1998. Plant evolution under domestication. Dordrecht, Netherlands: Kluwer Academic Publishers.

- 1999. On the origin of almond. Genetic Resources and Crop Evolution 46:143-147.

Landsberg, J. J. 1986. Integration of physiological information to evaluate fruit tree productivity. Acta Horticulturae 175:127-136.

Landsberger, B. 1967. The date palm and its byproducts according to the cuneiform sources. Archiv fuer Orientalforschung Beiheft 17. Graz, Austria: Ernst Weidner.

Lang, A. 1965. Physiology of flower initiation. In: Encyclopedia of plant physiology, ed., W. Ruhland, 15/1:1380-1536.

Lavee, S. 2006. Biennial bearing in olive (Olea europaea L.). Olea 25:5-13.

— and D. Zohary. 2012. Potential of genetic diversity and effect of geographic isolated resources in olive breeding. Israel Journal of Plant Sciences 59:3-13.

Li, L., X. Yao, C. Zhong, X. Chen, and H. Huang. 2010. Akebia: A potential new fruit crop in China. HortScience 45:4-10.
Liu, S-L. and K. L. Adams. 2010. Dramatic change in function and expression pattern of a gene duplicated by polyploidy created a paternal effect gene in Brassicaceae. Molecular Biology and Evolution 27:2817-2828.

Meyers, L. A. and D. A. Levin. 2006. On the abundance of polyploids in flowering plants. Evolution 60:1198-1206.

Miller, A. and B. Schaal. 2005. Domestication of a Mesoamerican cultivated fruit tree, Spondias purpurea. Proceedings of the National Academy of Sciences of the United States of America (PNAS) 102:12801-12806.

Mohamed, B. S. 2004. The contribution of Prunus webbii to almond evolution. Plant Genetic Resources Newsletter 140:9-13.

Monselise, S. P. and E. E. Goldschmidt. 1982. Alternate bearing in fruit trees: A review. Horticultural Reviews 4:128-173.

Moyle, L. C. and C. D. Muir. 2010. Reciprocal insights into adaptation from agricultural and evolutionary studies in tomato. Evolutionary Applications 3:409-421.

Mudge, K., J. Janick, S. Scofield, and E. E. Goldschmidt. 2009. A history of grafting. Horticultural Reviews 35: 437-493.

Mukherjee, S. K. 1953. The mango-Its botany, cultivation, uses and future improvement, especially as observed in India. Economic Botany 7:130-162.

Myles, S., A. R. Boyko, C. L. Owens, P. J. Brown, F. Grassi, M. K. Aradhya, B. Prins, A. Reynolds, J. M. Chia, D. Ware, C. D. Bustamante, and E. S. Buckler. 2011. Genetic structure and domestication history of the grape. Proceedings of the National Academy of Sciences of the United States of America (PNAS) 108:3530-3535.

Neal, J. M., C. M. Hardner, and C. L. Gross. 2010. Population demography and fecundity do not decline with habitat fragmentation in the rainforest tree Macadamia integrifolia (Proteaceae). Biological Conservation 143:2591-2600.

Neusner, J. 1991.The Talmud of the Land of Israel, Vol. 5, Shebiit, Chapter One. Chicago: The University of Chicago Press.

Palmer, J. W. 1988. Annual dry matter production and partitioning over the first 5 years of a bed system of Crispin/M.27 apple trees at four spacings. Journal of Applied Ecology 25:569-578.

Pruessner, A. H. 1920. Date culture in ancient Babylonia. The American Journal of Semitic Languages and Literatures 36:213-232. 
Robertson, K., E. E. Goldberg, and B. Igic. 2010. Comparative evidence for the correlated evolution of polyploidy and self-incompatibility in Solanaceae. Evolution 65-1:139-155.

Ross-Ibarra, J., P. L. Morell, and B. S. Gaut. 2007. Plant domestication, a unique opportunity to identify the genetic basis of adaptation. Proceedings of the National Academy of Sciences of the United States of America (PNAS) 104:8641-8648.

Sedgley, M. and A. R. Griffin. 1989. Sexual Reproduction of Tree Crops. London: Academic Press.

Simons, A. J. and R. R. B. Leakey. 2004. Tree domestication in tropical agroforestry. Agroforestry Systems 61:167-181.

Smith, P. 1976. Collapse of 'Murcott' tangerine trees. Journal of the American Society of Horticulture 101:23-25.

Sparks, D. 1986. Pecan. In: Handbook of Fruit Set and Development, ed., S. P. Monselise, 323-339. Boca Raton, Florida: CRC Press.

Stephan, B. R., I. Wagner, and J. Kleinschmit. 2003. Wild apple and pear. EUFORGEN Technical Guidelines for genetic conservation and use. Rome: EUFORGEN secretariat, c/o IPGRI.

Stevenson, M. T. and K. A. Shackel. 1998. Alternate bearing in pistachio as a masting phenomenon: Construction cost of reproduction versus vegetative growth and storage. Acta Horticulturae 470: 341-348.

Tachiki, Y. and Y. Iwasa. 2010. Both seedling banks and specialist seed predators promote the evolution of synchronized and intermittent reproduction (masting) in trees. Journal of Ecology 98:1398-1408.

Tanksley, S. D. 2004. The genetic, developmental, and molecular bases of fruit size and shape variation in tomato. Plant Cell 16: S181-S189.

Terral, J.-F., C. Newton, S. Ivorra, M. GrosBalthazard, C. Tito de Morais, S. Picq, M. Tengberg, and J.-C. Pintaud. 2012. Insights into the historical biogeography of the date palm (Phoenix dactilifera L.) using geometric morphometry of modern and ancient seeds. Journal of Biogeography 39:929-941.

Thrall, P. H., J. D. Bever, and J. J. Burdon. 2010. Evolutionary change in agriculture: The past, present and future. Evolutionary Applications 3:405-408.

Wareing, P. F. 1959. Problems of juvenility and flowering in trees. Journal of the Linnean Society of London (Botany) 56:282-289.

Webster, T. 2002. Dwarfing rootstocks: Past, present and future. The Compact Fruit Tree 35:67-72.

Wiersum, K. F. 1997. From natural forests to tree crops, co-domestication of forests and tree species, an overview. Netherlands Journal of Agricultural Science 45:425-438.

Vavilov, N. I. 1930. Wild progenitors of the fruit trees of Turkistan and Caucasus and the problem of the origin of fruit trees. Proceedings of the International Horticultural Congress 1930, pp. 271-286.

Velasco, R. [and 85 additional authors]. 2010. The genome of the domesticated apple (Malus X domestica Borkh) Nature Genetics 42:833-839.

Zeder, M. A., D. G. Bradley, E. Emshwiller, and B. D. Smith, eds. 2006. Documenting domestication: New genetic and archaeological paradigms. Berkeley, California: University of California Press. Zhang, C., K. Tanabe, S. Wang, F. Tamura, A. Yoshida, and K. Matsumoto. 2006. The impact of cell division and cell enlargement on the evolution of fruit size in Pyrus pyrifolia. Annals of Botany 98:537-543.

Zohary, D. 2002. Domestication of the carob (Ceratonia siliqua L.). Israel Journal of Plant Sciences 50:S141-S145.

- 2004. Unconscious selection and the evolution of domesticated plants. Economic Botany 58:5-10.

- and M. Hopf. 2000. Domestication of plants in the Old World, 3rd ed. Oxford, United Kingdom: University Press. - and P. Spiegel-Roy. 1975. Beginning of fruit growing in the Old World. Science 187:319-327. 